\title{
Effect of Irrigation Levels on Growth, Yield Attributes and Yield of Wheat
}

\author{
Dept. of Agronomy ${ }^{1}$ \\ Dept. of Seed Technology ${ }^{3}$ \\ Dept. of Horticulture, Sher-e-Bangla Agricultural University, Dhaka ${ }^{4}$ \\ Horticulture Development Division, BADC, Dhaka, Bangladesh ${ }^{2}$
}

M. N. Atikullah ${ }^{1}$, R. K. Sikder ${ }^{2}$, M. I. Asif ${ }^{3}$, H. Mehraj ${ }^{4}$ and A. F. M. Jamal Uddin ${ }^{4 *}$

Corresponding author : jamal4@yahoo.com

\begin{abstract}
The experiment was conducted during November 2012 to March 2013 in experimental field of Sher-e-Bangla Agricultural University, Dhaka, Bangladesh to find out the consequence of irrigation levels on growth, yield attributes and yield of wheat (BARI Gom-26). Four different irrigation levels viz. $I_{0}$ : No irrigation i.e. control; $I_{1}$ : Irrigation at 20 days after sowing (DAS) at crown root initiation stage; $I_{2}$ : Irrigation at 55 DAS at flowering stage) and $I_{3}$ : Irrigation at 75 $D A S$ at grain filling stage were used in the experiment using Randomized Complete Block Design with three replications. Results revealed that maximum dry matter content (18.8 $\mathrm{g} /$ plant $)$, crop growth rate $(C G R)\left(13.5 \mathrm{~g} \mathrm{~m}^{-2}\right.$ day $\left.\mathrm{y}^{-1}\right)$, relative growth rate $(R G R)\left(0.024 \mathrm{~g} \mathrm{~m}^{-2}\right.$ day $^{-}$ $\left.{ }^{1}\right)$ were found from $I_{1}$ which was statistically identical with $I_{2}$ whereas minimum from $I_{0}$. Plant height $(80.7 \mathrm{~cm})$, number of tiller (4.9/hill), number of spike (4.7/hill), number of spikelets (18.5/spike), spike length (19.2 cm), filled grains (29.3/spike), total grains (31.3/spike), 1000grains weight (44.4 g), yield (grain $3.4 \mathrm{t} / \mathrm{ha}$, straw $5.7 \mathrm{t} / \mathrm{ha}$ and biological $9.1 \mathrm{t} / \mathrm{ha}$ ) and harvest index were correspondingly showed higher results as of growth characters.
\end{abstract}

Key words: Wheat, irrigation levels, growth and yield

\section{Introduction}

In the environmental condition of Bangladesh wheat (Triticum aestivum L.) is a well adapted cereal crop for its vegetative growth and development. The popularity of wheat as staple food is increasing day by day in our country and wheat cultivation has been increased manifolds to meet up the food shortage in the country. However, the yield of the crop in the context of our country is low $\left(2.2 \mathrm{tha}^{-1}\right)$ in comparison to other countries of the world (FAO, 1997). The area, production and yield of wheat have been increasing dramatically based on the demand of over increasing population of Bangladesh during the last two decades, but its present yield is too low in comparison to some developed countries like Japan, France, Germany and UK producing 3.76, 7.12, 7.28, and 8.00 tha $^{-1}$, respectively (FAO, 2000). At present about 706.33 thousand hectares of land in Bangladesh is covered by wheat with the annual production of 1,592 thousand tons (BBS, 2011). Irrigation plays a vital role in terms of bringing good growth and development of wheat. Insufficient soil moisture affects both the germination of seed and uptake of nutrients from the soil. Irrigation frequency also has a significant influence on growth and yield of wheat (Khajanij and Swivedi, 1988). But in Bangladesh most of the farmers are not in a position to provide irrigation in different critical stages of wheat production because of the inadequate facility of irrigation devices and irrigation sources. These suggest that irrigation water should be supplied precisely at the peak period of crop growth, which may provide good yield of wheat. Shoot dry weight, number of grains, grain yield, biological yield and harvest 
index decreased to a greater extent when water stress was imposed at the anthesis stage while imposition of water stress at booting stage caused a greater reduction in plant height and number of tillers (Gupta et al., 2001). The lowest value corresponded to the treatment with irrigation during grain filling and under rainfed conditions (Bazza et al., 1999). From a survey Ahmed and Elias (1986) reported that in Bangladesh, lack of irrigation facilities was found to be a major constraint for 38\% wheat growers, and $25 \%$ of the farmers of Bangladesh could not grow wheat due to this problem. Information on the precise time of irrigation of wheat is inadequate in Bangladesh. Considering above circumstances the current study was undertaken to determine the effect of irrigation levels/times on growth, yield attributes and yield of wheat.

\section{Materials and Method}

This experiment was conducted at the experimental field of Sher-e-Bangla Agricultural University, Dhaka, Bangladesh during November 2012 to March 2013. Four different irrigation levels viz. $\mathrm{I}_{0}$ : No irrigation i.e. control; $\mathrm{I}_{1}$ : Irrigation at $20 \mathrm{DAS}$ (Crown root initiation stage); $\mathrm{I}_{2}$ : Irrigation at $55 \mathrm{DAS}$ (Flowering stage) and $\mathrm{I}_{3}$ : Irrigation at 75 DAS (Grain filling stage) was considered as three treatments following Randomized Complete Block Design with three replications. BARI Gom-26 was used as experimental material. Seeds were sown continuous with maintaining $20 \mathrm{~cm}$ line to line distance and plant to plant $5 \mathrm{~cm}$. Cowdung was applied $10 \mathrm{t} / \mathrm{ha}$ and fertilizers $\mathrm{N}, \mathrm{P}, \mathrm{K}$ and $\mathrm{S}$ were applied in the form of Urea $\left(220 \mathrm{~kg} \mathrm{ha}^{-1}\right)$, TSP $\left(180 \mathrm{~kg} \mathrm{ha}^{-1}\right)$, MoP $\left(50 \mathrm{~kg} \mathrm{ha}^{-1}\right)$ and Gypsum $\left(120 \mathrm{~kg} \mathrm{ha}^{-1}\right)$ respectively. The entire amount of TSP, MoP and Gypsum, $2 / 3^{\text {rd }}$ of Urea were applied during the final preparation of land. Rest of Urea was top dressed after first irrigation (BARI, 2006).

Data were collected on plant height, number of tillers, dry matter content, Crop Growth Rate (CGR), Relative Growth Rate (RGR), days required from sowing to flowering, days required from sowing to maturity, number of spikes, number of spikelets, spike length, number of filled grains, number of unfilled grains, number of total grains, weight of 1000-grains, grain yield, straw yield, biological yield and harvest index.

Data from five sample plants from each plot were collected and gently washed with tap water, thereafter soaked with paper towel. Fresh weight was taken immediately after soaking by paper towel. After taking fresh weight, the samples were oven dried at $70^{\circ} \mathrm{C}$ for 72 hours. These oven-dried samples were transferred into a desiccator and allowed to cool down to room temperature. Finally, dry weight was taken and expressed in grams.

Using the data on the leaf area and dry matter from each specific treatment, the following growth parameters were derived with the following mentioned calculation (Hunt, 1978).

- $\mathrm{CGR}=\left[(1 \div \mathrm{GA}) \times\left\{\left(\mathrm{W}_{2}-\mathrm{W}_{1}\right) \div\left(\mathrm{T}_{2}-\mathrm{T}_{1}\right)\right\}\right] \mathrm{g} \mathrm{m}^{-2} \mathrm{day}^{-1}$

Where, $\mathrm{GA}=$ Ground area $\left(\mathrm{m}^{2}\right), \mathrm{W}_{1}=$ Total dry weight at previous sampling date $\left(\mathrm{T}_{1}\right), \mathrm{W}_{2}=$ Total dry weight at current sampling date $\left(\mathrm{T}_{2}\right), \mathrm{T}_{1}=$ Date of previous sampling and $\mathrm{T}_{2}=$ Date of current sampling

- $\quad \mathrm{RGR}=\left\{\left(\mathrm{LnW}_{2}-\mathrm{LnW}_{1}\right) \div\left(\mathrm{T}_{2}-\mathrm{T}_{1}\right)\right\} \mathrm{g} \mathrm{g}^{-1} \mathrm{day}^{-1}$

Where, $\mathrm{W}_{1}=$ Total dry weight at previous sampling date (time $\left.\mathrm{T}_{1}\right), \mathrm{W}_{2}=$ Total dry weight at current sampling date (time $\mathrm{T}_{2}$ ), $\mathrm{T}_{1}=$ Date of previous sampling, $\mathrm{T}_{2}=$ Date of current sampling, $\mathrm{Ln}=$ Natural logarithm

Grains and straw obtained from $1 \mathrm{~m}^{-2}$ from each unit plot were sun-dried and weighed carefully. Dry weight of central $1 \mathrm{~m}^{2}$ area used to record grain yield $\mathrm{m}^{-2}$ and converted this into $\mathrm{tha}^{-1}$.

Biological yield was calculated with the following formula 
Biological yield $=$ Grain yield + Straw yield

Harvest Index was calculated using the following formula-

$\mathrm{HI}(\%)=[\{$ Economic yield $($ grain weight $)\} \div\{$ Biological yield $($ Total dry weight $)\}] \times 100$

Collected data were statistically analyzed using MSTAT-C computer package program. Mean were calculated and significance of difference among treatment means was estimated by Duncan Multiple Range Test (DMRT) at 5\% level of probability (Gomez and Gomez, 1984).

\section{Results and Discussion}

Statistically significant variation for plant height of wheat at different days after sowing (DAS) and at harvest was due to different irrigation levels. Tallest plant was found in $\mathrm{I}_{1}(80.7 \mathrm{~cm})$ while shortest in $\mathrm{I}_{0}(68.4 \mathrm{~cm})$ at harvest (Figure 1a). This result is in good agreement with the result of Islam (1997) who reported that plant height increased with increasing number of irrigations. Number of tillers of wheat showed major variation at different DAS due to different irrigation levels. Maximum number of tillers was found in $\mathrm{I}_{1}\left(4.9\right.$ hill $\left.^{-1}\right)$ which was statistically identical with $\mathrm{I}_{2}\left(4.6 \mathrm{hill}^{-1}\right)$ and $\mathrm{I}_{3}\left(4.5 \mathrm{hill}^{-1}\right)$ minimum in $\mathrm{I}_{0}\left(3.9\right.$ hill $\left.^{-1}\right)$ at harvest (Figure 1b). Application of two irrigations at crown root initiation stage and pre flowering stage ensured the optimum vegetative growth of the wheat with highest number of tillers hill ${ }^{-1}$ as referred by Meena et al, (1998). Gupta et al. (2001) reported that when water stress was imposed at the booting stage caused a greater reduction in number of tillers. Significant difference for dry matter content of wheat was found at diverse DAS due to different irrigation levels. Maximum dry matter content was found in $\mathrm{I}_{1}\left(18.8 \mathrm{~g}_{\text {plant }}{ }^{-1}\right)$ which was statistically similar with $\mathrm{I}_{2}\left(18.4 \mathrm{~g}\right.$ plant $\left.^{-1}\right)$ and $\mathrm{I}_{3}\left(17.9 \mathrm{~g}_{\text {plant }}{ }^{-1}\right)$ while minimum in $\mathrm{I}_{0}\left(15.8 \mathrm{~g}\right.$ plant $\left.{ }^{-1}\right)$ at harvest (Figure 1c).

Crop Growth Rate (CGR) of wheat was not varied significantly among the different irrigation levels at different DAS. Maximum CGR was found in $I_{1}\left(13.5 \mathrm{gm}^{-2} \mathrm{day}^{-1}\right)$ which was statistically identical with $\mathrm{I}_{3}\left(13.0 \mathrm{gm}^{-2} \mathrm{day}^{-1}\right)$ followed by $\mathrm{I}_{2}\left(12.8 \mathrm{gm}^{-2} \mathrm{day}^{-1}\right)$ and $\mathrm{I}_{3}\left(9.9 \mathrm{gm}^{-2} \mathrm{day}^{-1}\right)$ at $65-85$ DAS (Figure 2a). Similarly Relative Growth Rate (RGR) of wheat was also not varied meaningfully among the different irrigation levels at different DAS. Maximum RGR was found in $\mathrm{I}_{1}\left(0.024 \mathrm{gm}^{-2} \mathrm{day}^{-1}\right)$ followed by $\mathrm{I}_{2}$ and $\mathrm{I}_{3}\left(0.021 \mathrm{gm}^{-2} \mathrm{day}^{-1}\right)$ while minimum in $\mathrm{I}_{0}\left(0.019 \mathrm{gm}^{-2} \mathrm{day}^{-1}\right)$ at $65-85$ DAS (Figure 2a).

Early flowering was found in $\mathrm{I}_{1}$ (65.6 days) whereas late in $\mathrm{I}_{0}$ (70.7 days) which was statistically undistinguishable with $\mathrm{I}_{3}$ (68.9 days) (Table 1 ). Early maturity was found in $\mathrm{I}_{1}$ (115.3 days) while late in $\mathrm{I}_{0}$ (121.6 days) which was statistically identical with $\mathrm{I}_{2}$ and $\mathrm{I}_{3}$ (Table 1). Maximum number of spikes was found in $\mathrm{I}_{1}\left(4.7\right.$ hill $\left.^{-1}\right)$ which was statistically similar with $\mathrm{I}_{2}$ and $\mathrm{I}_{3}\left(4.2\right.$ hill $\left.^{-1}\right)$ while minimum was recorded from $\mathrm{I}_{0}\left(3.7\right.$ hill $^{-1}$ ) (Table 1). Maximum number of spikelets was found in $\mathrm{I}_{1}$ (18.5 spike $\left.^{-1}\right)$ which was statistically similar with $I_{2}\left(17.4\right.$ spike $\left.^{-1}\right)$ and $I_{3}\left(17.0\right.$ spike $\left.^{-1}\right)$ whereas minimum in $\mathrm{I}_{0}\left(14.4\right.$ spike $\left.^{-1}\right)$ (Table 1). Longest spike was found in $\mathrm{I}_{1}(19.2 \mathrm{~cm}$ ) which was statistically identical with $\mathrm{I}_{2}(18.7 \mathrm{~cm})$ and $\mathrm{I}_{3}(18.6 \mathrm{~cm})$ while shortest in $\mathrm{I}_{0}(16.9 \mathrm{~cm})$ (Table 1). Naser $(1996)$ reported that the highest number of grains per spike were recorded when two irrigations were applied. 

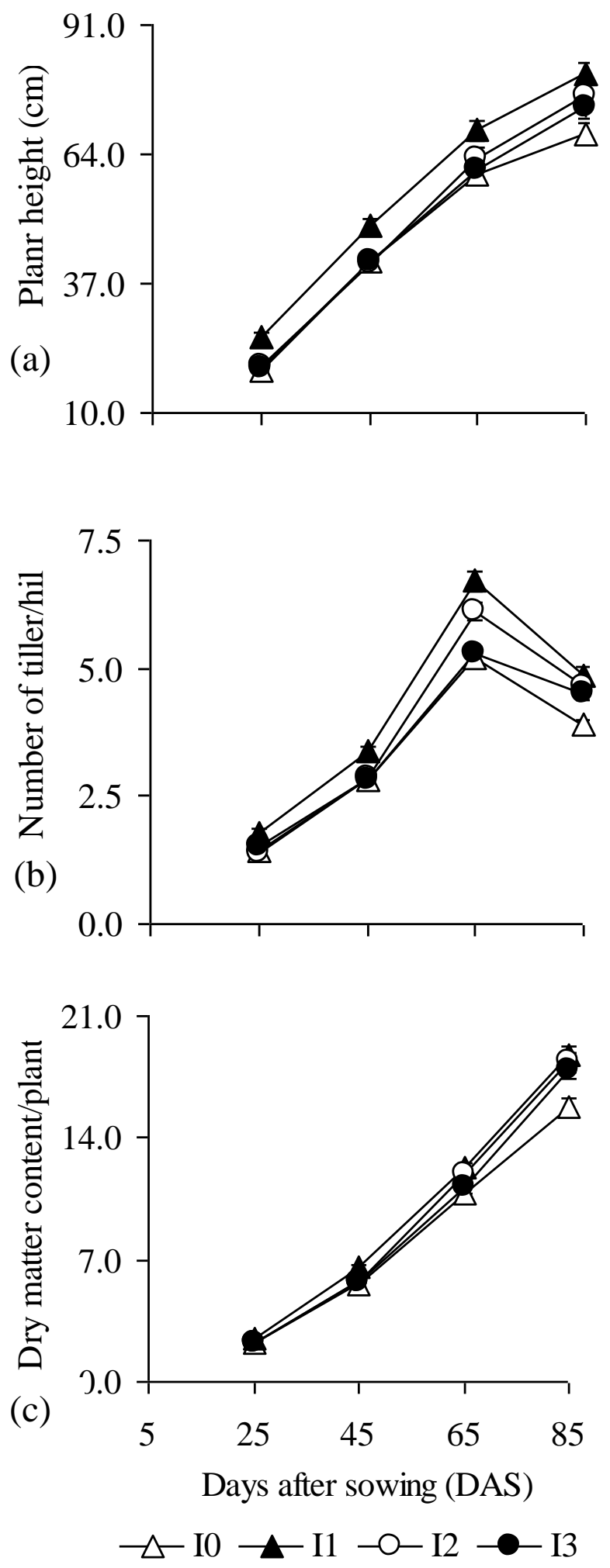

Figure 1. Effect of different irrigation level $\left(I_{0}, I_{1}, I_{2}, I_{3}\right)$ on (a) plant height, (b) number of tillers and (c) dry matter content of wheat 


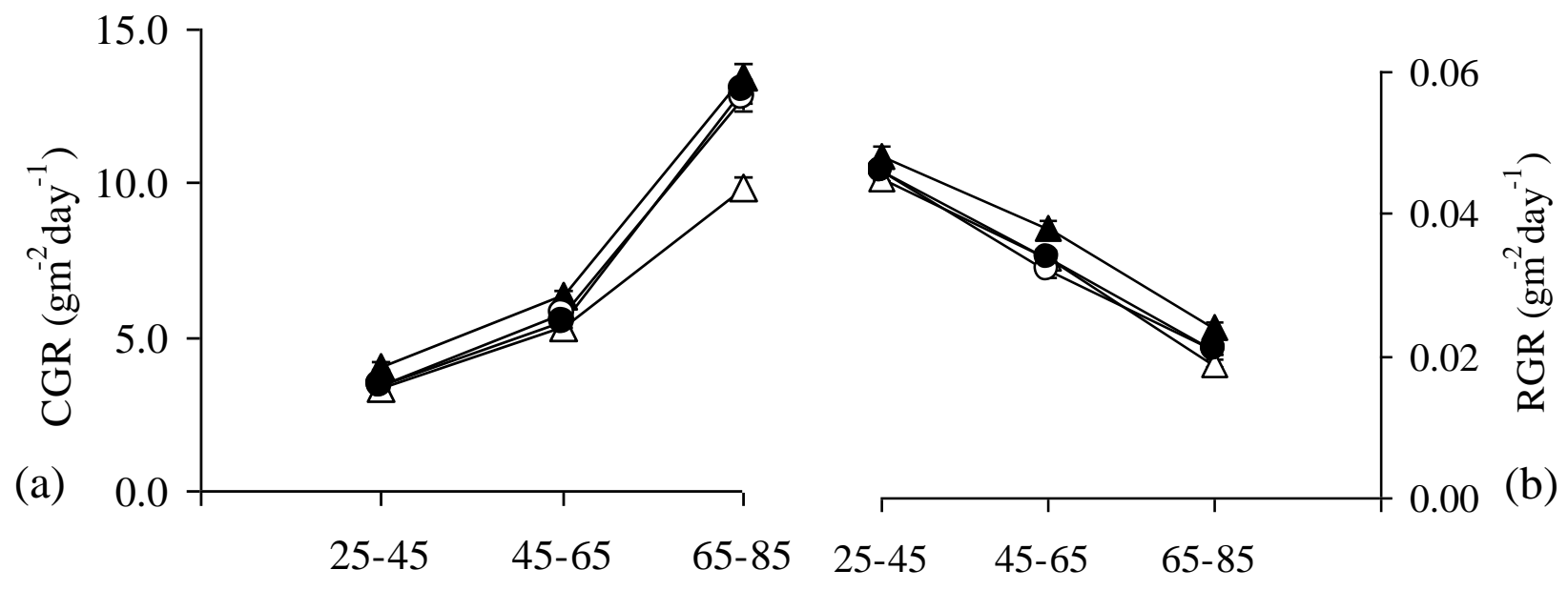

Days after sowing (DAS)

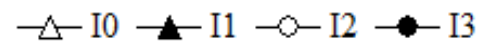

Figure 2. Effect of irrigation levels on (a) CGR and (b) RGR to wheat

Table 1. Effect of seed irrigation levels on duration and spike related characters

\begin{tabular}{|c|c|c|c|c|c|c|c|c|c|c|}
\hline \multirow{2}{*}{ Treatment } & \multicolumn{4}{|c|}{ Days required from sowing to } & \multicolumn{4}{|c|}{ Number of } & \multirow{2}{*}{\multicolumn{2}{|c|}{$\begin{array}{l}\text { Spike length } \\
\quad(\mathrm{cm})\end{array}$}} \\
\hline & \multicolumn{2}{|c|}{ flowering } & \multicolumn{2}{|c|}{ maturity } & \multicolumn{2}{|c|}{ Spikes hill $^{-1}$} & \multicolumn{2}{|c|}{ Spikelets spike $^{-1}$} & & \\
\hline $\mathrm{I}_{0}$ & 70.7 & $\mathrm{a}$ & 121.6 & $\mathrm{a}$ & 3.7 & B & 14.4 & B & 16.9 & $\mathrm{~b}$ \\
\hline $\mathrm{I}_{1}$ & 65.6 & $\mathrm{c}$ & 115.3 & b & 4.7 & A & 18.5 & A & 19.2 & $\mathrm{a}$ \\
\hline $\mathrm{I}_{2}$ & 68.4 & $\mathrm{~b}$ & 118.9 & $a b$ & 4.2 & A & 17.4 & A & 18.7 & $\mathrm{a}$ \\
\hline $\mathrm{I}_{3}$ & 69.4 & $a b$ & 118.2 & $a b$ & 4.2 & A & 17.0 & A & 18.6 & $\mathrm{a}$ \\
\hline LSD 0.05 & 1.3 & & 3.7 & & 0.7 & & 1.9 & & 1.2 & \\
\hline CV $(\%)$ & 5.8 & & 4.8 & & 4.7 & & 8.5 & & 5.4 & \\
\hline
\end{tabular}

* In a column means having similar letter (s) are statistically identical and those having dissimilar letter (s) differ significantly as per 0.05 level of probability

Maximum number of filled grains was found in $I_{1}\left(29.3 \mathrm{spike}^{-1}\right)$ which was statistically identical with $\mathrm{I}_{2}\left(27.6\right.$ spike $\left.^{-1}\right)$ while minimum in $\mathrm{I}_{0}\left(23.2\right.$ spike $^{-1}$ ) (Table 2). Gupta et al. (2001) reported that number of grains decreased to a greater extent when water stress was imposed at the anthesis stage. Minimum unfilled grains was recorded from $\mathrm{I}_{1}\left(2.0\right.$ spike $\left.^{-1}\right)$ while maximum unfilled grains from $\mathrm{I}_{0}\left(3.6\right.$ spike $\left.\mathrm{s}^{-1}\right)$ (Table 2). Different sowing date showed significant variation in number of grains. Maximum number of total grains was found in $\mathrm{I}_{1}\left(31.3\right.$ spike $\left.^{-1}\right)$ which was statistically identical with $\mathrm{I}_{2}\left(30.6\right.$ spike $\left.^{-1}\right)$ and $\mathrm{I}_{3}\left(29.6\right.$ spike $\left.^{-1}\right)$ while minimum in $\mathrm{I}_{0}\left(26.8\right.$ spike $\left.^{-1}\right)$ (Table 2). However, Islam (1996) observed that irrigation had no influence of grains per spike. Maximum 1000 grains weight of wheat was recorded from $\mathrm{I}_{1}(44.4 \mathrm{~g})$ followed by $\mathrm{I}_{2}(42.1 \mathrm{~g})$ and $\mathrm{I}_{3}(41.5 \mathrm{~g})$ while minimum from $\mathrm{I}_{0}(39.0 \mathrm{~g})$ (Table 2). Islam (1996) observed that irrigation had no influence of 1000-grains weight. Grain yield of wheat showed significant variation due to different sowing date. Maximum grain yield was recorded from $\mathrm{I}_{1}$ $\left(3.4\right.$ tha $\left.^{-1}\right)$ which was statistically identical with $\mathrm{I}_{3}\left(3.3\right.$ tha $\left.^{-1}\right)$ and $\mathrm{I}_{2}\left(3.2\right.$ tha $\left.^{-1}\right)$ while minimum from $\mathrm{I}_{0}$ $\left(2.6\right.$ tha $\left.^{-1}\right)$ (Table 2). Bazza et al. (1999) reported that one water application during the tillering stage allowed the yield to be lower only than that of the treatment with three irrigations However, Meena $e t$ al. (1998) reported that wheat grain yield was the highest with 2 irrigations (2.57 tha ${ }^{-1}$ in 1993 and 2.64 tha $^{-1}$ ) at flowering and/or crown root initiation stages. Generally wheat sown in November to ensure optimal crop growth and avoid high temperature and after that if wheat sown in the field it faces high range of temperature for its growth and development as well as yield potential. Islam et al. (1993) reported that late planted wheat plants faced a period of high temperature stress during reproductive stages causing reduced kernel number spike ${ }^{-1}$ as well as the reduction of seed yield. 
Table 2. Effect of irrigation levels on yield related characters and yield of wheat

\begin{tabular}{|c|c|c|c|c|c|c|c|c|c|c|c|c|c|c|c|}
\hline \multirow{3}{*}{$\begin{array}{l}\text { Treatment } \\
\mathrm{I}_{0}\end{array}$} & \multicolumn{6}{|c|}{ Grains spike $^{-1}$} & \multirow{2}{*}{\multicolumn{2}{|c|}{$\begin{array}{l}\text { Weight of } \\
1000 \\
\text { grains (g) }\end{array}$}} & \multicolumn{6}{|c|}{ yield $\left(\mathrm{t} \mathrm{ha}^{-1}\right)$} & \multirow{2}{*}{$\begin{array}{c}\text { Harvest } \\
\text { index }(\%)\end{array}$} \\
\hline & \multicolumn{2}{|c|}{ filled } & \multicolumn{2}{|c|}{ unfilled } & \multicolumn{2}{|c|}{ total } & & & \multicolumn{2}{|c|}{ grain } & \multicolumn{2}{|c|}{ straw } & \multicolumn{2}{|c|}{ biological } & \\
\hline & 23.2 & c & 3.6 & $\mathrm{a}$ & 26.8 & b & 39.0 & $\mathrm{~b}$ & 2.6 & b & 5.0 & b & 7.6 & c & 34.3 \\
\hline $\mathrm{I}_{1}$ & 29.3 & $\mathrm{a}$ & 2.0 & d & 31.3 & $\mathrm{a}$ & 44.4 & $\mathrm{a}$ & 3.4 & $\mathrm{a}$ & 5.7 & $\mathrm{a}$ & 9.1 & $\mathrm{a}$ & 37.7 \\
\hline $\mathrm{I}_{2}$ & 27.6 & $a b$ & 2.9 & b & 30.6 & $\mathrm{a}$ & 42.1 & $a b$ & 3.2 & $\mathrm{a}$ & 5.4 & $\mathrm{a}$ & 8.7 & $\mathrm{~b}$ & 37.2 \\
\hline $\mathrm{I}_{3}$ & 26.9 & b & 2.6 & $\mathrm{c}$ & 29.6 & $\mathrm{a}$ & 41.5 & $a b$ & 3.3 & $\mathrm{a}$ & 5.5 & $\mathrm{a}$ & 8.7 & b & 37.3 \\
\hline LSD0 & 2.5 & & 0.2 & & 1.9 & & 3.1 & & 0.5 & & 0.3 & & 0.4 & & 1.3 \\
\hline CV (\%) & 7.2 & & 7.6 & & 6.8 & & 4.8 & & 6.8 & & 6.2 & & 4.8 & & 5.9 \\
\hline
\end{tabular}

" In a column means having similar letter (s) are statistically identical and those having dissimilar letter (s) differ significantly as per 0.05 level of probability

$\mathrm{I}_{1}$ showed maximum straw yield $\left(5.7 \mathrm{tha}^{-1}\right)$ which was statistically similar with $\mathrm{I}_{2}\left(5.4 \mathrm{t} \mathrm{ha} \mathrm{h}^{-1}\right)$ and $\mathrm{I}_{3}$ $\left(5.5 \mathrm{t} \mathrm{ha}^{-1}\right.$ ) while minimum from $\mathrm{I}_{0}\left(5.0 \mathrm{t} \mathrm{ha}^{-1}\right)$ (Table 2). Maximum biological yield was found in $\mathrm{I}_{1}$ $\left(9.1 \mathrm{t} \mathrm{ha}^{-1}\right)$ which was statistically identical with $\mathrm{I}_{2}$ and $\mathrm{I}_{3}\left(8.7 \mathrm{t} \mathrm{ha}^{-1}\right)$ while minimum recorded from $\mathrm{I}_{0}$ $\left(7.6 \mathrm{t} \mathrm{ha}^{-1}\right)$ (Table 2). Gupta et al. (2001) reported that biological yield decreased to a greater extent when water stress was imposed at the anthesis stage. There was significant variation for harvest index of wheat due to different irrigation levels. Numerically, maximum harvest index was found in $\mathrm{I}_{1}$ $(37.7 \%)$ which was statistically identical with $\mathrm{I}_{2}(37.2 \%)$ and $\mathrm{I}_{3}(37.3 \%)$ while minimum in $\mathrm{I}_{0}(34.3 \%)$ (Table 2). Gupta et al. (2001) reported that harvest index decreased to a greater extent when water stress was imposed at the anthesis stage.

\section{Conclusion}

It may be concluded that irrigation at root initiation and flowering state has greater impact on crop growth rate, relative growth rate and dry matter content of wheat. As such, growth characteristics, yield attributes and yield of wheat were related to irrigation levels as found in this experiment. When irrigation in wheat field is limited to once, then it should be given at crown root initiation stage to obtain better growth and development of wheat to achieve higher yield.

\section{References}

Ahmed, M. and Elias, S. M. (1986). Socio-economic status of wheat cultivation in Bangladesh. Proc. $3^{\text {rd }}$ National Wheat Training Workshop. BARI-WRC and CIMMYT-CIDA Wheat Program. Dhaka. p. 176.

BARI (Bangladesh Agricultural Research Institute) (2006). Krishi Projukti Hat Boi. BARI. Joydevpur, Gazipur. p. 14.

Bazza, M. J., Sadaria, S. G. and Patel, J. C. ( 1999 ). Wheat and sugar beet with irrigation management practices through water-deficit irrigation. Indian J. Agril. Sci. 69(13): 431-435.

BBS (Bangladesh Bureau of Statistics) (2011). Monthly Statistical Bulletin, Bangladesh. Statistics Division. Ministry of Planning. Government of the Peoples Republic of Bangladesh. Dhaka. pp. 72.

FAO (1997). Production Year Book. Food and Agricultural of the United Nations Rome, Italy. 49: 201-212.

FAO(2000). Production Year Book. Food and Agricultural of the United Nations Rome, Italy. 54: 176-186.

Gomez, K. A. and Gomez, A. A. (1984). Statistical Procedure for Agricultural Research (2 ${ }^{\text {nd }}$ edn.). Int. Rice Res. Inst., A Willey Int. Sci., pp. 28-192.

Gupta, P. K., Gautam, R. C. and Ramesh, C. R. (2001). Effect of water stress on different stages of wheat cultivation. Plant Nutri. and Fert. Sci. 7(2): 33-37. 
Hunt, R. (1978). Plant growth analysis. The institute of Biology's studies in Biology No. 96. Edward Arnold (Publishers) Limited, London, UK.

Islam, M. M. (1997). Effect of irrigation on different growth stages of wheat cultivation. Bangladesh J. Tr. and Dev. 6(1): 41-44.

Islam, M. T. (1996). A review on the effect of soil moisture stress on the growth phases of wheat. Bangladesh J. Tr. and Dev. 5(2): 55-64.

Islam, N., Ahmed, S. M., Razzaque, M. A., Sufian, A. and Hossain, M. A. (1993). A study on the effect of seeding dates on the yield of wheat varieties. Bangladesh. J. Agril. Res. 18(1): 102-107.

Khajanij, S. N. and Swivedi, R. K. ( 1988 ). Response of wheat (Triticum aestivum L.) to irrigation and fertilizer mixture under late condition. Bhartiya Krishi Anusandhan Patrika 3(1): 37-42.

Meena, B. S., Gautam, R. C. and Kaushik, S. K. (1998). Pearlmillet (Pennlsetum glaucum) and wheat (Triticum aestivum) cropping sequence as influenced by cultural, nutritional and irrigation factors under limited moisture conditions. Indian J. Agril. Sci. 68(10): 638-643.

Naser, H. M. (1996). Response of wheat to irrigation. MS Thesis, Dept. of Soil Sci., Bangladesh Agril. Univ., Mymensingh. p. 1-77.

\section{Citation for this article (APA Style):}

Atikullah, M. N., Sikder, R. K., Asif, M. I., Mehraj, H. \& Jamal Uddin, A. F. M. (2014). Effect of Irrigation Levels on Growth, Yield Attributes and Yield of Wheat. Journal of Bioscience and Agriculture Research, 02(02), 83-89.

Retrieved December 14, 2014, from http://www.journalbinet.com/current-issue-jbar-1.html 